\title{
Social measures, financial support to maintain, increase population in some European countries
}

\author{
Kinga Emese Zsido ${ }^{{ }^{*}}$ \\ ${ }^{1}$ University of Medicine, Pharmacy, Science and Technology "George Emil Palade” of Targu Mures, Gh. \\ Marinescu 38, Targu Mures, 540139 Mures, Romania
}

\begin{abstract}
The evolution of the number of the population in many countries, even at European level, gives signs of concern, of which we should be aware: the significant decrease of the population, the negative changes in its structure can have negative and drastic economic and social effects if the governments do not intervene reasonable time. The implementation of measures must be well thought out, with the possibility of financial support and maintained for a long time, so that the expected effects appear. In Europe, some governments (especially in Eastern Europe) have already assumed this responsibility, implemented a series of measures to keep the youth in the country, to increase the number of children, with the purpose of increasing the population and balancing its structure. The paper presents a comparative analysis of the measures implemented by three European countries (Poland, Romania and Hungary) in order to increase the population in the following decades.
\end{abstract}

Keywords: population, financial support, raising children.

\section{JEL Classification: J11}

(ㄷ) 2019 Publised by ACTA MARISIENSIS, SERIA OECONOMICA, Publisher University Press Târgu Mureș, issued on behalf of University of Medicine, Pharmacy, Sciences and Technology "George Emil Palade" from Tîrgu Mureș, România

\footnotetext{
* Corresponding author: Kinga Emese Zsido e-mail: kinga.zsido@umfst.ro
} 


\section{INTRODUCTION}

After the change of the political regime in Romania (after 1989), but much more accentuated after Romania's accession to the European Union (January 1, 2007), we are constantly witnessing negative changes in the number and structure of the population. The opening of the borders, the elimination of the conditions imposed for employment abroad for the Romanian citizens, the major differences registered in the incomes obtained by the different categories of employees and many other causes, have led to the phenomenon of citizen emigration. This phenomenon is present in most Eastern European countries. Besides the phenomenon of emigration, another phenomenon with a negative effect on the number and structure of the population of Romania is represented by the decrease of fertility and birth rate. Families are no longer engaged in raising 2-3 or even more children, the current trend regarding the number of "assumed" children is 1 or 2 (both at home and abroad). Europe is facing (among others) demographic problems.

\section{POPULATION AND ITS EVOLUTION IN HUNGARY, POLAND AND ROMANIA}

Population structure, demographic problems (in the long term) can adversely affect the economic and social development of a country, so it is very important to identify the phenomenon and especially to take measures to improve, improve the situation. The measures taken in this regard must be maintained in the long term, the possible results will appear only after 3-5 years.

I chose to analyze the situation of three Eastern European countries facing the above mentioned problems, namely Poland, Romania and Hungary. In these countries, there is a drastic trend of population decline (Figure no. 1, 2. and 3.) and a constantly decreasing birth rate (Table no. 1).

Figure no.1 - Evolution of population in Hungary

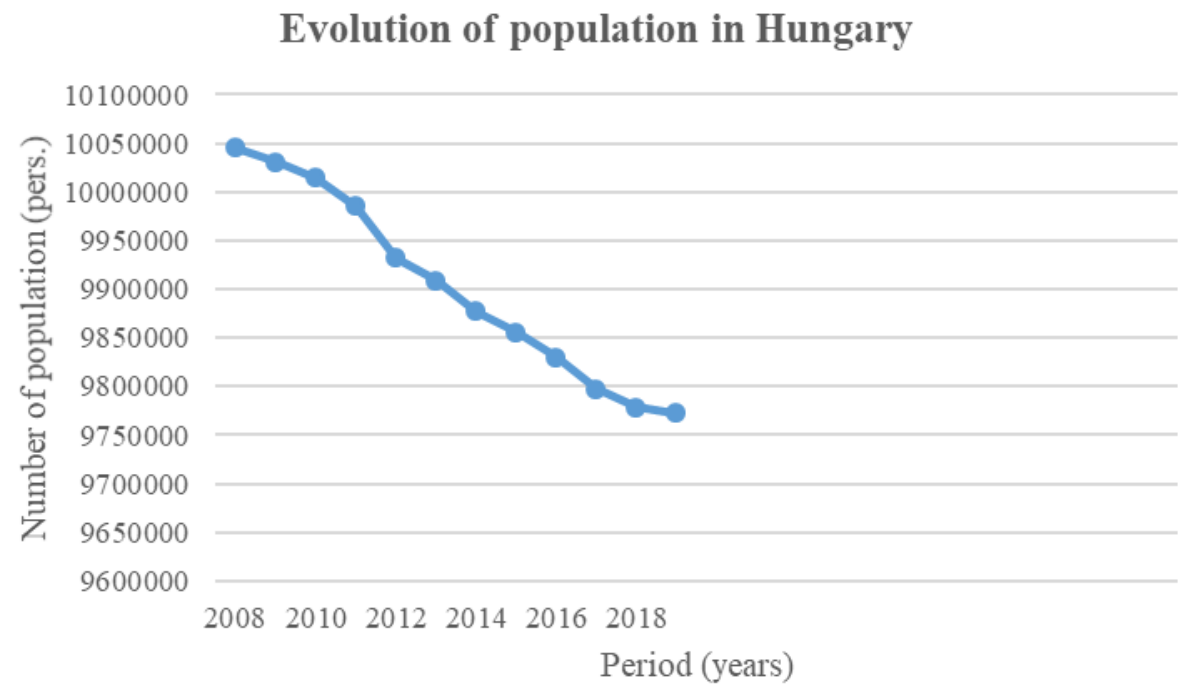

Source: Eurostat database, link:

https://ec.europa.eu/eurostat/tgm/table.do?tab=table \&plugin=1\&language $=$ en $\&$ pcode $=$ tps 00001 
ACTA MARISIENSIS, SERIA OECONOMICA

Online:ISSN 2668-3989, ISSN L 2668-3148

Print:ISSN 2668-3148, ISSN L 2668-3148

doi: 10.2478/amso-2019-0006

Figure no.2 - Evolution of population in Poland

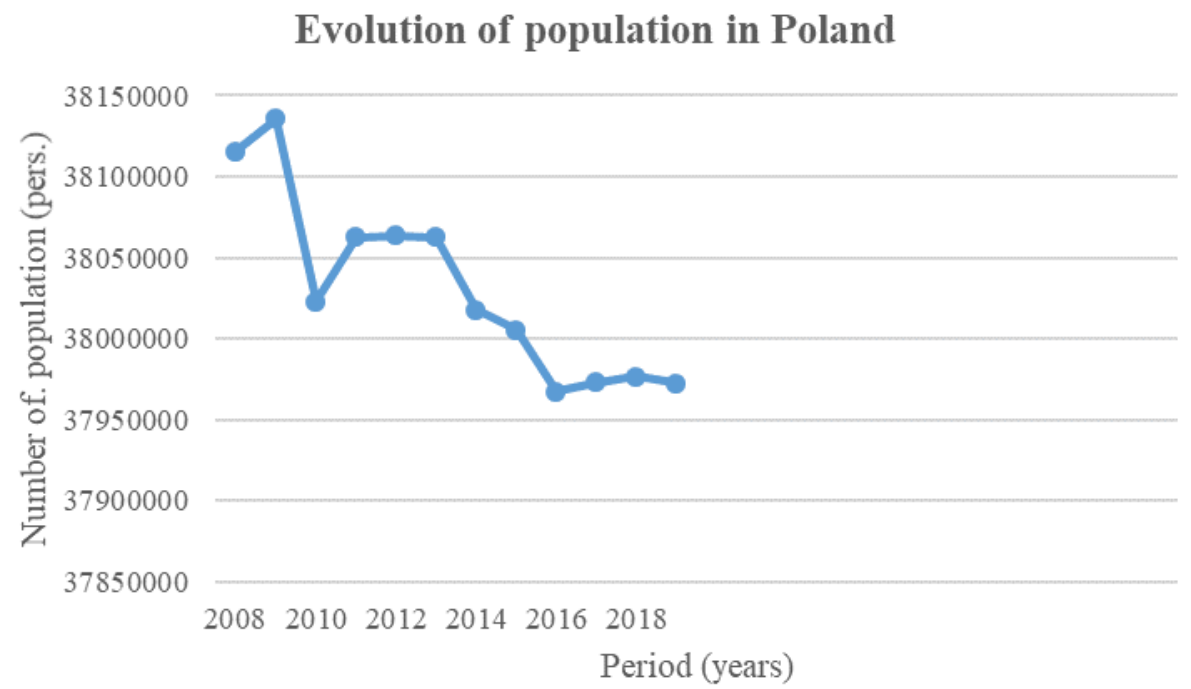

Source: Eurostat database, link:

https://ec.europa.eu/eurostat/tgm/table.do?tab=table \&plugin $=1 \&$ language $=e n \& p$ code $=$ tps00001

Figure no.3 - Evolution of population in Romania

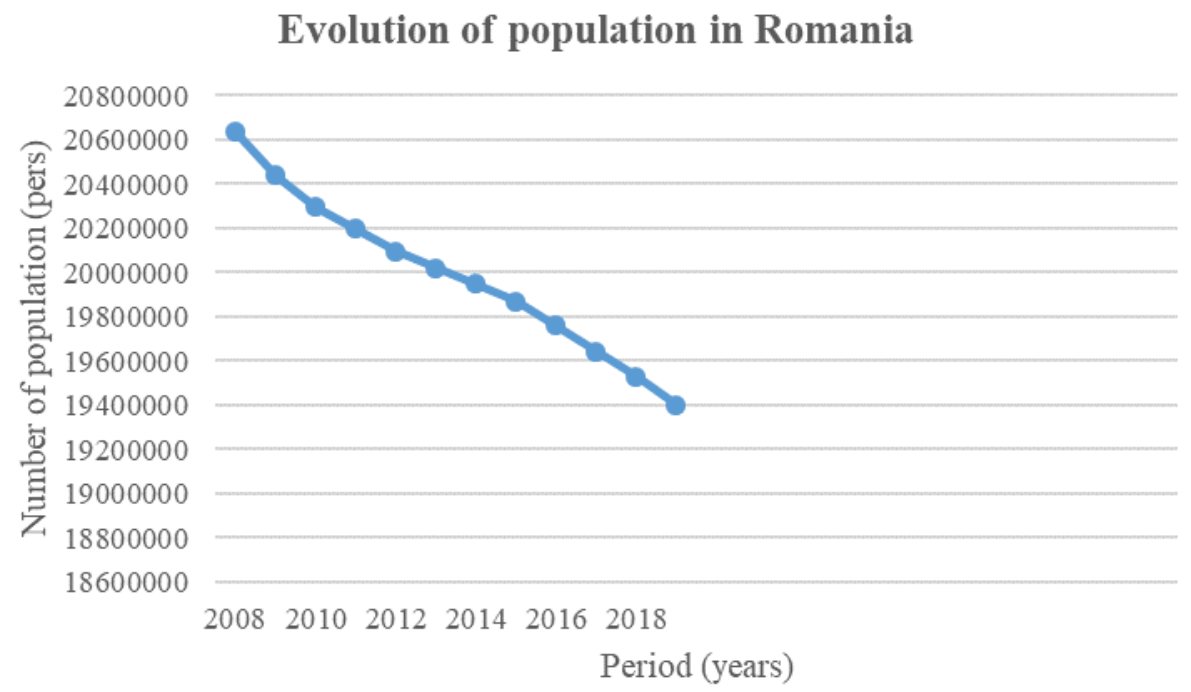

Source: Eurostat database, link:

https://ec.europa.eu/eurostat/tgm/table.do?tab=table \&plugin=1\&language $=e n \& p c o d e=t p s 00001$ 
Table no.1-Birth rate in Europe (\%o)

\begin{tabular}{|l|r|r|r|r|r|r|r|r|r|r|r|}
\hline GeolYear & $\mathbf{2 0 0 8}$ & $\mathbf{2 0 0 9}$ & $\mathbf{2 0 1 0}$ & $\mathbf{2 0 1 1}$ & $\mathbf{2 0 1 2}$ & $\mathbf{2 0 1 3}$ & $\mathbf{2 0 1 4}$ & $\mathbf{2 0 1 5}$ & $\mathbf{2 0 1 6}$ & $\mathbf{2 0 1 7}$ & $\mathbf{2 0 1 8}$ \\
\hline Austria & 9,3 & 9,2 & 9,4 & 9,3 & 9,4 & 9,4 & 9,6 & 9,8 & 10 & 10 & 9,7 \\
\hline Belgium & 11,9 & 11,8 & 11,9 & 11,7 & 11,5 & 11,3 & 11,2 & 10,8 & 10,8 & 10,5 & 10,3 \\
\hline Bulgaria & 10,4 & 10,9 & 10,2 & 9,6 & 9,5 & 9,2 & 9,4 & 9,2 & 9,1 & 9 & 8,9 \\
\hline Czechia & 11,5 & 11,3 & 11,2 & 10,4 & 10,3 & 10,2 & 10,4 & 10,5 & 10,7 & 10,8 & 10,7 \\
\hline Denmark & 11,8 & 11,4 & 11,4 & 10,6 & 10,4 & 10 & 10,1 & 10,2 & 10,8 & 10,6 & 10,6 \\
\hline France & 12,9 & 12,8 & 12,9 & 12,7 & 12,6 & 12,4 & 12,4 & 12 & 11,8 & 11,5 & 11,3 \\
\hline Germany & 8,3 & 8,1 & 8,3 & 8,3 & 8,4 & 8,5 & 8,8 & 9 & 9,6 & 9,5 & 9,5 \\
\hline Greece & 10,7 & 10,6 & 10,3 & 9,6 & 9,1 & 8,6 & 8,5 & 8,5 & 8,6 & 8,2 & 8,1 \\
\hline Hungary & 9,9 & 9,6 & 9 & 8,8 & 9,1 & 9 & 9,5 & 9,4 & 9,7 & 9,7 & 9,6 \\
\hline Italy & 9,8 & 9,6 & 9,5 & 9,2 & 9 & 8,5 & 8,3 & 8 & 7,8 & 7,6 & 7,3 \\
\hline Poland & 10,9 & 10,9 & 10,9 & 10,2 & 10,1 & 9,7 & 9,9 & 9,7 & 10,1 & 10,6 & 10,2 \\
\hline Romania & 10,8 & 10,9 & 10,5 & 9,7 & 10 & 9,4 & 10 & 10,2 & 10,4 & 10,3 & 9,6 \\
\hline Slovakia & 10,7 & 11,4 & 11,2 & 11,3 & 10,3 & 10,1 & 10,2 & 10,3 & 10,6 & 10,7 & 10,6 \\
\hline Spain & 11,3 & 10,6 & 10,4 & 10,1 & 9,7 & 9,1 & 9,2 & 9 & 8,8 & 8,4 & 7,9 \\
\hline Sweden & 11,9 & 12 & 12,3 & 11,8 & 11,9 & 11,8 & 11,9 & 11,7 & 11,8 & 11,5 & 11,4 \\
\hline United & & & & & & & & & & & \\
Kingdom & 12,9 & 12,7 & 12,9 & 12,8 & 12,8 & 12,1 & 12 & 11,9 & 11,8 & 11,4 & 11 \\
\hline
\end{tabular}

Source: EUROSTAT database:

https://ec.europa.eu/eurostat/tgm/download.do?tab=table \&plugin $=1 \&$ language $=$ en \&pcode $=t p s 00204$

The green areas in the table show the most favorable situation compared to the countries presented (for a certain year), and the red ones indicate the most unfavorable situations (with the lowest birth rate) compared to the other countries. Germany, Greece, Italy and in recent years Spain have the lowest birth rates, while a favorable situation (compared to the countries presented) is present in the case of Sweden, Czech Republic, France, etc. Romania and Hungary have a birth rate below $10 \%$, and Poland slightly above this value.

The table perfectly shows the general tendency of the birth rate decrease, not only in the three analyzed countries, but also on European level. It is clear that the population of Romania is constantly decreasing, the possible causes were listed by ROMAN and VOICU (2010), such as: negative external migration, increase in the mortality rate exceeding the birth rate, etc.

A progression of the evolution of the population from Europe was made by the European Commission (Table 2), which shows how the population of the countries would appear if the existing factors remained unchanged during the analyzed period.

Table no. 2 - Population forecast of European countries

\begin{tabular}{|c|c|c|c|c|c|c|c|c|}
\hline time & 2018 & 2020 & 2030 & 2040 & 2050 & 2060 & 2070 & 2080 \\
\hline $\begin{array}{l}\text { EU } \\
28 \\
\text { countries }\end{array}$ & 512.379 .225 & 514.292 .912 & 520.712 .470 & 524.655 .224 & 523.708 .357 & 517.098 .344 & 509.548 .113 & 504.019 .027 \\
\hline Belgium & 11.398 .589 & 11.487 .179 & 11.911 .998 & 12.295 .636 & 12.571 .061 & 12.731 .525 & 12.897 .951 & 13.066 .355 \\
\hline Bulgaria & 7.050 .034 & 6.943 .254 & 6.402 .584 & 5.979 .800 & 5.605 .134 & 5.217 .922 & 4.809 .607 & 4.470 .250 \\
\hline Czechia & 10.610 .055 & 10.674 .178 & 10.738 .001 & 10.648 .484 & 10.611 .979 & 10.479 .307 & 10.196 .812 & 10.004 .952 \\
\hline Denmark & 5.781 .190 & 5.839 .809 & 6.165 .570 & 6.370 .062 & 6.475 .023 & 6.553 .902 & 6.621 .759 & 6.659 .281 \\
\hline Germany & 82.792 .351 & 83.159 .604 & 83.823 .479 & 83.525 .424 & 82.672 .493 & 81.467 .826 & 80.620 .373 & 80.000 .620 \\
\hline
\end{tabular}




\title{
sciendo
}

\author{
ACTA MARISIENSIS, SERIA OECONOMICA \\ Online:ISSN 2668-3989, ISSN L 2668-3148 \\ Print:ISSN 2668-3148, ISSN L 2668-3148
}

doi: $10.2478 /$ amso-2019-0006

\begin{tabular}{|l|r|r|r|r|r|r|r|r|} 
Greece & 10.741 .165 & 10.691 .204 & 10.367 .846 & 10.032 .362 & 9.622 .242 & 9.052 .676 & 8.477 .995 & 8.054 .104 \\
\hline Spain & 46.658 .447 & 47.054 .924 & 48.071 .225 & 49.245 .586 & 49.932 .997 & 49.376 .897 & 48.391 .357 & 47.968 .015 \\
\hline France & 66.926 .166 & 67.204 .763 & 69.116 .880 & 70.926 .211 & 71.587 .879 & 71.673 .255 & 72.032 .320 & 72.605 .730 \\
\hline Italy & 60.483 .973 & 60.233 .172 & 58.940 .837 & 57.710 .684 & 55.859 .604 & 52.995 .452 & 50.156 .210 & 48.186 .055 \\
\hline Hungary & 9.778 .371 & 9.739 .030 & 9.520 .613 & 9.271 .789 & 9.041 .782 & 8.806 .659 & 8.499 .508 & 8.237 .799 \\
\hline Austria & 8.822 .267 & 8.908 .676 & 9.364 .680 & 9.666 .339 & 9.836 .451 & 9.880 .512 & 9.889 .642 & 9.890 .748 \\
\hline Poland & 37.976 .687 & 37.968 .244 & 37.397 .916 & 36.174 .048 & 34.861 .135 & 33.462 .408 & 31.669 .769 & 29.841 .357 \\
\hline Romania & 19.530 .631 & 19.282 .488 & 18.063 .702 & 17.409 .228 & 16.735 .514 & 15.944 .658 & 15.059 .393 & 14.333 .839 \\
\hline Slovenia & 2.066 .880 & 2.083 .676 & 2.079 .967 & 2.056 .567 & 2.024 .248 & 1.961 .700 & 1.893 .609 & 1.846 .638 \\
\hline Slovakia & 5.443 .120 & 5.455 .848 & 5.420 .101 & 5.264 .291 & 5.087 .967 & 4.865 .556 & 4.572 .716 & 4.294 .987 \\
\hline Sweden & 10.120 .242 & 10.348 .449 & 11.523 .061 & 12.540 .808 & 13.392 .498 & 14.002 .352 & 14.500 .979 & 14.906 .727 \\
\hline $\begin{array}{l}\text { United } \\
\text { Kingdom }\end{array}$ & 66.273 .576 & 67.086 .777 & 71.468 .174 & 75.294 .576 & 78.290 .066 & 80.311 .998 & 82.132 .803 & 83.644 .641 \\
\hline
\end{tabular}

Source: EUROSTAT database, link:

https://ec.europa.eu/eurostat/databrowser/view/tps00002/default/table?lang=en

The statistical data, the forecasts made show that there is a need for intervention, immediate interventions and the implementation of long-term measures.

\section{SOCIAL MEASURES WITH THE AIM OF INCREASING THE NUMBER OF POPULATION, STOPPING OF EMIGRATION}

Given the trends in the charts above and the data presented in the tables, it was / is inevitable to take measures to stop and long-term increase in population numbers. It is interesting to analyze, if and if so, how the governments of some countries are concerned about this phenomenon, what measures and incentives/support are given to families to encourage youth to stay in the country, as well as financial/social support for raising children. Fortunately, there are such concerns, there are already programs and measures implemented in different countries.

Next I will present the existing programs, the measures implemented for the support of families, encouraging the birth of children, stopping emigration in Poland, Hungary and Romania.

\subsection{Stimulation program in / to support the birth of children in Poland}

Family Support Program in Poland (Family 500+, Rodzina 500+): according to the program adopted and implemented in February 2016, each family with two, three or more children, receives a monthly support of 500 zloty after each child up to the age of one 18 years of the child (according to the current exchange rate this amount equals 118 Euro / children). This amount is not taxable and is independent of the status of parents and the level of income earned. As of July 2019 this support of 500 zloty has already been paid after the birth of the first child. This support is independent of the type of family: married couples, cohabiting parents, a single parent, etc.). The 500+ program does not affect the other existing social assistance programs.

This program was and is very welcome and perceived by the population of Poland. 


\subsection{Complex social and financial measures aimed the acquisition of houses or apartmants for families, to increase the number of born children, the maintenance of youth in the country, in Hungary.}

Family support program in Hungary: in Hungary there are a number of measures introduced to support families, to encourage young people and parents to want and have at least 2-3 childrens. In addition to encouraging and supporting the desire to have children, the measures taken by the Hungarian government are also aimed at encouraging families to settle in their own home. In general, the quantum of support depends and increases with the number of children. In Hungary, the following family aids are implemented, functioning and enjoying of great success and popularity:

- The CSOK program (Családok Otthonteremtési Kedvezménye = family home creation program), which represents a non-refundable financial support, depending on the number of children and on the purchased home.

Table no. 3. -Non-refundable support in the case of purchasing a "home"

\begin{tabular}{|c|c|c|c|c|}
\hline & \multicolumn{3}{|c|}{ Non-refundable support in the case of purchasing } \\
\hline \multirow{2}{*}{$\begin{array}{c}\text { Number of } \\
\text { children }\end{array}$} & Newly built homes & EURO & HUF & EURO \\
\cline { 2 - 5 } & 600.000 & 1.820 & 600.000 & 1.820 \\
\hline 1 & 1.600 .00 & 7.880 & 1.430 .000 & 4.333 \\
\hline 2 & 10.000 .000 & 30.303 & 2.750 .000 & 8.333 \\
\hline
\end{tabular}

Source: edited by the author

- CSOK program, for real estate loans. This measure aims at subsidizing by the state the interest paid after the contracted real estate loans.

- Support (non-refundable) for the purchase of new cars (at least 7 people) for families with at least 3 children.

Table no.4.- Support (non-refundable) for the purchase of new cars

\begin{tabular}{|l|l|}
\hline \multicolumn{2}{|c|}{ Support (non-refundable) for the purchase of new cars, for families with at least 3 children } \\
\hline The duration of the program & 1 iuly $2019-31$ december 2022 \\
\hline The value of the support & $\begin{array}{l}2.500 .000 \text { HUF }=7.575 \text { EURO, but not more than } \\
50 \% \text { of the value of the car }\end{array}$ \\
\hline The object of the support & Purchase of new (at least) 7 person car \\
\hline Conditions & $\begin{array}{l}\text { Holding a driving license and the right to allow } \\
\text { children for at least 3 children }\end{array}$ \\
\hline Other requirements & The car cannot be sold for at least 3 years \\
\hline
\end{tabular}

- $\quad$ Credit / child waiting credit (Babaváró hitel): this credit supports families who do not yet have children, but would like at least one. Characteristics of the loan:

o Maximum value 10,000,000 HUF (approx. 30,000 EURO) - without real estate guarantees

o Free to use

o No interest

o Maximum value of the monthly rate 50,000 HUF (150 EURO)

o Possibility of deleting the loan repayment. 
Conditions to be fulfilled: can be requested by married couples, the age of the wife should be between 18-40 years, 3 years uninterrupted of employment contract / health insurance.

- In order to reduce the emigration of young graduates with higher education, those who receive budget places in the years of the faculty, respectively masters, after finishing the studies in the next 20 years, must demonstrate at least 5 years of employment contract in the country (Hungary), otherwise they will be obliged to reimburse the value of the education fee, according to the Law on Higher Education CCIV. since 2011.

\subsection{Measures to stop emigration, increase of population in Romania}

In Romania, measures to support and encourage families and young people not to leave the country are primarily concerned with wages. There is a continuous increase of the minimum wage in the economy (Table no. 5) and a significant increase of the wages in the budgetary environment. The wages from the budgetary environment have reached, even in certain areas, exceeded the wages of Poland or Hungary (www.profit.ro), this in the conditions where the gross domestic product (GDP) in Romania is well below of the level of the two countries (Hungary 13,690 EURO per capita, Poland 12,920 EURO per capita and Romania 10,420 EURO per capita in 2018, according to eurostat.com). Unfortunately, these wage increases target only part of the population.

Table no. 5: The evolution of the net minimum wage on the economy in Romania

\begin{tabular}{|r|r|}
\hline Years & \multicolumn{1}{|c|}{ Wage } \\
\hline 2019 & 1.263 lei \\
\hline 2018 & 1.162 lei \\
\hline 2017 & 1.065 lei \\
\hline 2016 & 925 lei \\
\hline 2015 & 776 lei \\
\hline 2014 & 724 lei \\
\hline 2013 & 668 lei \\
\hline
\end{tabular}

Sousce: own edited by the author

The First Home (Prima Casa) program has existed in Romania since 2009, targeting young people who want to buy a home and have no money to pay an advance of more than $5 \%$ of the total price of the property. The Romanian state guarantees a good part of the loans granted by the banks, thus, for the loans taken for old houses, the state guarantees $40 \%$ of the amount, and for the loans taken for new buildings $50 \%$ of the total amount will be provided by the First Guarantee Fund Home. Although this program was / is a successful program, the lack of funds is still a major problem in supporting this program in the future.

\section{4. - Other facilities in the analyzed countries}

In addition to the programs, the measures presented above, in each country there are also social measures aimed at persons who are on maternity leave (child-raising allowance), state allowance for children up to the age of 18, reduction / income tax exemption. The size of the income tax reduction is significant in Hungary, where depending on the number of existing children, the amount of the reduction can reach up to 33,000 HUF (100 EURO) after each child, per month, if their number is 3 or more. 


\section{CONCLUSIONS}

Of the three countries presented, the series of measures designed and implemented by the Hungarian government to maintain and increase population numbers in the coming decades, far outweighs the weak, insufficient and risky attempts of the other countries. These measures should be maintained for a long time so that the effects are visible. The financial support of these measures requires a significant effort, an effort that is supported by continuous economic growth (according to European Commission data the economic growth registered by Hungary in 2018 was $5.1 \%$, in Poland $5.1 \%$ and in Romania by $4 \%$ ). We can say with certainty that the example of Hungary is an example to follow, the government is investing in the future of the country, trying to provide stability and significant financial support to families who want and have 2-3 or even more children.

At the opposite pole is China, where since 1979 there is a "one child" policy (with some exceptions). The purpose of this policy is to control the size of the population. Of course there are also positive examples of significant, continuous and conscious population growth, such as in Israel, a country with an average of three children per woman (Israel has the highest fertility rate in the OECD (Organization for Economic Co-operation and Development).

\section{Bibliography:}

Agnieszka S. (2016). "Family 500+": A new family income-supporting benefit in Poland, European Social Policy Network (ESPN) Flash Report.

Roman, M., Voicu, C. (2010). Câteva efecte socioeconomice ale migrației forței de muncă asupra țărilor de emigrație. Cazul României, Economie teoretică și aplicată, Vol. XVII, No. 7(548), pp. 50-65

Government Emergency Ordinance no. 111/2010 Romania

OG 45/2019 Hungary, regarding the non-refundable support for the purchase of a new car for families with at least 3 children

Law on personal income tax CXVII of 1995, as subsequently amended in Hungary

$\underline{\text { https://ec.europa.eu/eurostat/tgm/download.do?tab=table } \& \text { plugin }=1 \& \text { language }=\text { en } \& p \operatorname{pode}=\operatorname{tps} 00}$ $\underline{204}$

https://ec.europa.eu/eurostat/tgm/table.do?tab=table\&init=1\&language=en \&pcode=tec $00001 \& p l u$ gin=1

https://www.profit.ro/must-read/analiza-trei-ani-cresteri-fulminante-salariilor-bugetarilorremuneratia-functionarilor-romani-explodat-castiga-bine-cei-ungaria-polonia-au-luat-3-ori-multibani-plus-fata-privat-19124804 